\title{
Will Growth of Technology Lift up the Economic Status of Farmers?
}

\author{
T. Amose ${ }^{1}$, Dr. KR. Jeyakumar ${ }^{2}$
}

${ }^{1} \mathrm{Ph} . \mathrm{D}$ Research scholar in the Research Department of Economics, Arumugam Pillai Seethai Ammal College, Thiruppatur, Sivagangai District of Tamilnadu. (Mail ID: amose212@gmail.com).

${ }^{2}$ Associate Professor in the Research Department of Economics, Arumugam Pillai Seethai Ammal College, Thiruppatur, Sivagangai District of Tamilnadu. (Mail ID: dspjeyam@yahoo.in).

\begin{abstract}
As a very hot news that spread through out the state Tamilnadu, India that the formers who produced tomatos are dumped aside of road without bringing to market for domestic cooking consumption. Usually, the agricultural zaid commodities are not brings expected profit to the producers due to perishable character and gets low price at the markets in any situation. Tomato is zaid crop but it availing in all seasons and price of it will be also differing Moreover, crop in the zaid season gets very less price in the market but the level of production is high. Due to stable demand and substitute commodities are the cause for emerging low price in the market. As a remedy for this problem, recent research found that the rotten tomatos is good source to generate electricity. Hence, This empirical report brought out the real situation of zaid crop tomato in the market and plights of formers due to decreased price. Moreover, report suggests to the government that have to follow a procurement price for zaid crops also, to empower the economic status of formers followed by the execution of technology for alternative purposes.
\end{abstract}

Keywords-Tomato, Production, Zaid, Price, Electricity.

Prevailing problems in the marketing of agricultural products are dumping the producers (farmers) in the deep ocean of tears which not paves way to escape from the economic burden and gives afflicts to survive as farmers prolong is being common trend in every crops season. Generally, agricultural productions can be divided in to three types as the seasons forthcoming every year. Thus, June-september (4 months) crops are kharif, Octobermarch (6 months) crops are rabi and April-june (3 months) crops are called Zaid ${ }^{[1]}$.

Month wise availability of Tomato in India

\begin{tabular}{|l|l|}
\hline $\begin{array}{c}\text { Period of } \\
\text { Harvest }\end{array}$ & \multicolumn{1}{|c|}{ Areas } \\
\hline $\begin{array}{l}\text { January- } \\
\text { March }\end{array}$ & $\begin{array}{l}\text { Bihar, Eastern UP, MP, Orissa, foot hills } \\
\text { of Uttarakhand, Andhra Pradesh, Assam }\end{array}$ \\
\hline April- May & Haryana, Punjab, Karnataka, Rajasthan \\
\hline June-July & H.P. Uttarakhand, Tamil Nadu, Punjab, \\
\hline
\end{tabular}

\begin{tabular}{|l|l|}
\hline & Gujarat \\
\hline $\begin{array}{l}\text { August- } \\
\text { September }\end{array}$ & Andhra Pradesh, Himachal Pradesh, \\
Uttarakhand, Maharashtra, Gujarat \\
\hline $\begin{array}{l}\text { October- } \\
\text { November }\end{array}$ & Chattisgarh, Tamil Nadu \\
\hline December & $\begin{array}{l}\text { Andhra Pradesh, Rajasthan, Chattisgarh, } \\
\text { Madhya Pradesh, Orissa }\end{array}$ \\
\hline
\end{tabular}

Source:

http://agriexchange.apeda.gov.in/Market\%20Profile/one/ TOMATO.aspx ${ }^{[2]}$

As being the problems of marketing of zaid crops in tamilnadu and other states of India farmers are economically affected too and many of them feeling shame about being as an agricultural products producers due to falling a price of the productivity that holding them lest they improve economically and to be under debt. Tomatto as zaid crop that price is fallen from the range of Rs.30-60 to Rs.1-3 and now is being in the markets at very cheap cost which not meet the minimum production cost of the producer and directs further production trend to be declined for short period. Moreover, as a recent incident proclaimed that the tonnes of tomatos are dropped into lakes and ponds without commercial and further production purposes. A writer sreedevi jeyarajan says that lakes and ponds in tamilnadu are becoming red beds due to price falling of tomato and Dheiva sigamani, State President, Tamil farmers union said that Rayakottai, Krishnagiri district and Valappadi in Salam district are having great tomato markets but tomatoes are dumped into nearby lakes as an agitation of farmers ${ }^{[3]}$. Because, price falling of tomato is being unrecoverable to obtain harvesting costs to manage the production function for long time.

\section{Why the price is fallen?}

Quantity and quality of the products also determines the price along with market demand of the same to meet maximum profit and recover harvesting costs. Dheiva sigamani says that farmers are inspired to produce maximum level of tomato production ratio due to it is 
short season crop, existence of high market price that was few months ago, limited water supply required for irrigation purpose in the production process of tomato are indirectly led to bring excess production ${ }^{[3]}$. Demand for tomato was not increased to increase the production level and it will not increased if horizontal level of supply not decreased. As we know the zaid crops are wants minimum level of water to be supplied and climates should be cool. Hence, farmers are forwarded to increase the level of tomato production without prediction of future outcomes. Thus, minimum demand and over supply has brought the price to be fallen for tomato in the market..

\section{Public Opinion}

Why dose the Minimum Support Price (MSP) is not been helpful to farmers?. As we know the MSP is usually implemented for two types of crops such as Kharif and rabi because these are long time season crops and having sustainable demand for it in the market. But, zaid crops are apart from the characters of the remain because products are available much in the short season and there is no possible way of leading sustainable production trend. So, India's agricultural price policy neglectes MSP system for such a crops comes under zaid. Although, some states are forwarding to bring MSP for zaid crops also as Rs.225 for one quvindal in Karnataka, Rs.5 per kg in Hyderabad and Rs.6 per kg in tamilnadu etc. Moreover, very practically, S. Narayan, former Economic Adviser to the Prime Minister, said that "Rice and wheat are standard items and the government has been procuring them over a long period of time. But the case of potato and tomato is different with so many variants. To standardise and give the correct price would be difficult" and also stated United Progressive Alliance (UPA) regime between 2004 and 2014 was regular increase in the minimum support price and farmers were better off. But, after 2014, the MSP was not increased. But, the cost has gone up to farmers distress as an instances ${ }^{[4]}$.

\section{Way to recover the loss}

Why does the farmers have dumped?. Here two reasons are visualize that the farmers are agitates against government due to use less MSP in the short season and if tomatoes put forth to store, rotten one will make rotten all so better be thrown out instead of to be sold. Hence, Truths about farmers is that they are innocent, illiterate and also being zero awareness about technical growth and global advances. But, rest of farmers what steps has been taken to bear their economic loss and burden even we have sufficient potential to further process is still questionable.

'A team of scientists is exploring an unusual source of electricity — damaged tomatoes that are unsuitable for sale at the grocery store. Their pilot project involves a biological-based fuel cell that uses tomato waste left over from harvests in Florida.The researchers present their work at the 251st National Meeting \& Exposition of the American Chemical Society (ACS). ACS, the world's largest scientific society, is holding the features of more than 12,500 presentations on a wide range of science topics.

"We have found that spoiled and damaged tomatoes left over from harvest can be a particularly powerful source of energy when used in a biological or microbial electrochemical cell," says Namita Shrestha, who is working on the project. "The process also helps purify the tomato-contaminated solid waste and associated waste water." Shrestha is a graduate student in the lab of Venkataramana Gadhamshetty, Ph.D., P.E., at the South Dakota School of Mines \& Technology. They are collaborating on this project with Alex Fogg, an undergraduate chemistry major at Princeton University. Other project collaborators include Daniel Franco, Joseph Wilder and Simeon Komisar, Ph.D., at Florida Gulf Coast University.

Tomatoes are a key crop in Florida, notes Gadhamshetty. He stresses that the project is important to the state because Florida generates 396,000 tons of tomato waste every year, but lacks a good treatment process. Gadhamshetty began working on the topic as a professor at Florida Gulf Coast University. "The project began a few years ago when Alex visited lab in Fort Myers, Florida, said that he was interested in researching a local problem, especially local tomatoes grown in our state and the large waste treatment issue," Gadhamshetty says. "We wanted to find a way to treat this waste that, when dumped in landfills, can produce methane - a powerful greenhouse gas - and when dumped in water bodies, can create major water treatment problems." So, the team developed a microbial electrochemical cell that can exploit tomato waste to generate electric current. Shrestha explains, "Microbial electrochemical cells use bacteria to break down and oxidize organic material in defective tomatoes." The oxidation process, triggered by the bacteria interacting with tomato waste, releases electrons that are captured in the fuel cell and become a source of electricity. The natural lycopene pigment in tomatoes, the researchers have found, is an excellent mediator to encourage the generation of electrical charges from the damaged fruits. Some of their results proved to be counterintuitive. "Typical biotechnological applications require, or at least perform better, when using pure chemicals, compared to wastes," Gadhamshetty notes. "However, we found that electrical performance using defective tomatoes was equal or better than using pure substrates. These wastes can be a rich source of indigenous redox mediators and carbon, as well as 
electrons."At the moment, the power output from their device is quite small: 10 milligrams of tomato waste can result in 0.3 watts of electricity. But the researchers note that with an expected scale up and more research, electrical output could be increased by several orders of magnitude.

According to calculations by Shrestha, there is theoretically enough tomato waste generated in Florida each year to meet Disney World's electricity demand for 90 days, using an optimized biological fuel cell. "Our research question at this time is to investigate the fundamental electron transfer mechanisms and the interaction between the solid tomato waste and microbes," Gadhamshetty notes. They plan to improve the cell by determining which of its parts - electrode, electricityproducing bacteria, biological film, wiring - are resisting the flow of electricity. Then they will tweak or replace that part.The team acknowledges funding from the National Science Foundation, National Aeronautics and Space Administration, Electric Power Research Institute and the Office of Research \& Graduate Studies at the Florida Gulf Coast University.The American Chemical Society is a nonprofit organization chartered by the U.S. Congress. With more than 158,000 members, ACS is the world's largest scientific society and a global leader in providing access to chemistry-related research through its multiple databases, peer-reviewed journals and scientific conferences. Its main offices are in Washington, D.C., and Columbus, Ohio ${ }^{[5]}$.

\section{Government contribution to recover the loss}

As a government contribution to standardise the economic level of farmers, necessary steps need to be taken to prevent such dumping energy potential crops. While MSP is not been effective, that is good if better technical powers adopted to the appropriate field. Sufficient awareness need to forwarded among farmers regarding technical advances in supporting primary sector. Steps need to taken for collect all solid waste (vegetables) or damaged and rotten tomatoes in preparing energy for future use. When short time price falling accumulates in the market, farmers need to approach the technical filed which ready to collect agri-wastes to the energy production. Appropriate price need to fix for rotten tomato that should be purchased from farmers as it should be a way of recovering losses in the market. And also technical filed should be motivated in this function and sufficient support should be delivered to the same. Price determination for rotten tomatoes should be based on the value of further alternative energy but not compared with the price of tomatoes that is in the markets. Thus, if policy makers brings technological growth to the primary sector to protect it value for future purposes, farmers also be able to develop themselves economically and many problems regarding production and marketing of agricultural products will be solved.

\section{REFERENCES}

[1] 'Major Crops of India', https://www.google.co.in/amp/s/www.gktoday.in/gk /major-crops-of-india/amp/.

[2] 'Tomato' Agrixchange, http://agriexchange.apeda.gov.in/Market\%20Profile/ one/TOMATO.aspx.

[3] Sreedevi Jayarajan, 2018, 'TN farmers dump tomato harvests into lakes after prices drop', The News Minute,

https://www.google.co.in/amp/s/www.thenewsminut e.com/article/tn-farmers-dump-tomato-harvestslakes-after-prices-drop-77230\%3famp.

[4] 'Difficult to provide MSP for potato, tomato, says Narayan', 2018, The Hindu,

https://www.google.co.in/amp/www.thehindu.com/n ews/national/tamil-nadu/difficult-to-provide-mspfor-potato-tomato-saysnarayan/article22787140.ece/amp/.

[5] San Diego, 2016, 'Generating electricity with tomato waste',

https://www.acs.org/content/acs/en/pressroom/newsr eleases/2016/march/tomato-waste.html. 